\title{
Dampak Strategi Bauran Pemasaran Dan Kualitas Pelayanan Terhadap Tingkat Partisipasi Anggota Sebagai Pengguna Koperasi
}

\author{
Tiris Sudrartono \\ PT. Polyfin Canggih Bandung Jawa Barat \\ Tiris.sudrartono@gmail.com
}

\begin{abstract}
ABSTRAK
Penelitian ini bertujuan untuk mengetahui seberapa besar dampak Strategi Bauran Pemasaran dan Kualitas Pelayanan terhadap Tingkat Partisipasi Anggota Sebagai pengguna Koperasi, sample dalam penelitian ini adalah 97 orang anggota koperasi karya sejahtera PT. Polyfin Canggih sebagai responden yang menjawab pernyataan dari kuiseioner yang dibagikan kemudian dilakukan analisis secara kuantitatif dan kualitatif. Data dari pengujian persamaan diketahui nilai F-hitung sebesar 114,782 sementara dengan $\square=5 \%$ diperoleh nilai F-tabel sebesar 3,94. Artinya F-stat > F-tabel $(114,782>3,94)$ hal ini berarti bahwa pada derajat keyakinan $95 \%$, variabel Startegi bauran pemasaran dan Kualitas Pelayanan mempunyai pengaruh yang signifikan secara bersama-sama terhadap variabel Tingkat partisipasi Anggota sebagai Pengguna Koperasi. Koefisien determinasi $\left(\mathrm{R}^{2}\right)$ sebesar 0,709. Tingkat Partisipasi Anggota sebesar 70,9\% dipengaruhi oleh Strategi Bauran Pemasaran dan Kualitas Pelayanan dan sisanya sebesar $\quad 29,1 \%$ dipengaruhi oleh faktor lain di luar model.
\end{abstract}

Kata kunci : strategi bauran pemasaran, Kualitas pelayanan.

\section{ABSTRACT}

This study aims to find out how big the impact of Marketing Mix Strategy and Service Quality to Member Participation Level As a cooperative user, the sample in this research is 97 members of cooperative work of prosperous PT.Polyfin Canggih as respondents who answered the statement of the questionnaire distributed then analyzed quantitatively and qualitatively. Data from equation test is known F-count value is 114,782 while with $\square=5 \%$ obtained F-table value 3,94. This means that F-stat> F-table (114,782> 3,94) means that at $95 \%$ confidence level, Marketing Strategy and Service Quality variables have a significant influence simultaneously on the variable Member participation rate as a Cooperative User. The coefficient of determination (R2) is 0.709. Member Participation Rate of 70.9\% is influenced by the Marketing Mix Strategy and Service Quality and the balance of $29.1 \%$ is influenced by other factors outside the model.

Keywords: marketing mix strategy, quality of service.

\section{PENDAHULUAN}

\section{Latar Belakang}

Bangsa Indonesia dalam menghadapai persaingan ekonomi tersebut secara terus menerus giat melaksanakan pembangunan di segala bidang kehidupan, agar pembangunan tersebut dapat berjalan dengan baik maka perlu adanya peran aktif langsung dari masyarakat dalam pelaksanaanya, hal ini guna mencapai tujuan yang ingin dicapai oleh bangsa Indonesia, salah satunya adalah memperbaiki dan meningkatkan kesejahteraan masyarakat melalui pembangunan ekonomi. Antara lain dengan meningkatkan pembangunan ekonomi melalui pembentuk suatu lembaga ekonomi yang dapat mensejahterakan masyarakat, yang sejalan dengan
Undang-Undang Dasar 1945 Pasal 33 ayat 1 bahwa :"Perekonomian disusun sebagai usaha bersama berdasar atas asas kekeluargaan".

Dalam menjalankan kegiatan usahanya, KOPKAR "Karya Sejahtera" mempunyai dua unit usaha yaitu :

1) Unit Simpan Pinjam, Kegiatan utama unit Simpan Pinjam adalah menghimpun dana dari anggota dalam bentuk simpanan dan kemudian menyalurkannya kembali dana tersebut kepada anggota dalam bentuk pemberian pinjaman.

2) Unit Mini Market, Kegiatan utama Unit Mini Market adalah menyediakan dan melayani kebutuhan bahan pokok dan kebutuhan lain 
sehari hari para anggotanya dalam pemenuhan kebutuhan ekonomi tersebut anggota dapat melakukan transaksi secara tunai dan secara kredit.

Tabel 1 Perkembangan Belanja Anggota Koperasi Karya Pada Unit Mini Market Tahun 2011- 2015

\begin{tabular}{|c|c|c|c|c|c|c|c|}
\hline $\begin{array}{c}\text { Tahun dan } \\
\text { Jumlah } \\
\text { anggota }\end{array}$ & $\begin{array}{c}\text { Belanja Tunai } \\
\text { Non anggota } \\
\text { (Rp) }\end{array}$ & $\begin{array}{c}\text { Belanja Tunai } \\
\text { Anggota } \\
\text { (Rp.) }\end{array}$ & $\begin{array}{c}\text { Belanja Kredit } \\
\text { Anggota } \\
\text { (Rp) }\end{array}$ & $\begin{array}{c}\text { Jml Belanja } \\
\text { Anggota } \\
(\mathrm{Rp})\end{array}$ & $\begin{array}{c}\text { Belanja/ } \\
\text { bulan } \\
\text { Anggota } \\
\text { (Rp) }\end{array}$ & $\begin{array}{c}\text { Standard } \\
\text { Kontrak } \\
\text { Belanja } \\
\text { (Rp) }\end{array}$ & $\begin{array}{l}(\%) \\
\text { /Bln }\end{array}$ \\
\hline $\begin{array}{c}2011 \\
1.662 \text { Anggota }\end{array}$ & 617,925,300.- & 185,392,617.- & 2,948,943,001.- & 3,134,335,618.- & 156,779.- & 1,200,000.- & 13.0 \\
\hline $\begin{array}{c}2012 \\
1.584 \text { Anggota }\end{array}$ & 733,050,200.- & 195,108,200.- & 3,097,659,382.- & 3,292,767,582.- & 173,230.- & 1,200,000.- & 14.4 \\
\hline $\begin{array}{c}2013 \\
1.515 \text { Anggota }\end{array}$ & 568,104,900.- & 238,307,300.- & 3,119,803,183.- & 3,358,110,483.- & 184,714.- & 1,200,000.- & 15.3 \\
\hline $\begin{array}{c}2014 \\
\text { 1.451 Anggota }\end{array}$ & 300,199,100.- & 225,425,000.- & 3,655,072,847.- & 3,880,497,847.- & 222,863.- & 1,200,000.- & 19.0 \\
\hline $\begin{array}{c}2015 \\
\text { 1.361 Anggota }\end{array}$ & 477,557,400.- & 184,550,100.- & 3,682,612,852.- & 3,864,162,952.- & 236,600.- & 1,200,000.- & 19.7 \\
\hline
\end{tabular}

Pada tabel 1 dapat disampaikan bahwa tingkat belanja yang dilakukan oleh anggota di Unit mini market Koperasi Karya Sejahtera baik yang dilakukan secara tunai maupun yang dilakukan secara kredit masih di bawah Rp. 250,000.- per bulan per anggota, pada tahun 2015 anggota yang berbelanja di Mini Market Koperasi rata-rata sebesar $19 \%$ dari batas maksimal belanja kredit di Koperasi, hal ini dapat dikatakan bahwa anggota dalam pemenuhan kebutuhan ekonominya terutama sembako di koperasi tidak sebanding dengan kebutuhan yang harus dipenuhi dalam satu bulan hal tersebut disadarkan pada survey pendahuluan bahwa paling rendah kebutuhan anggota yang harus dipenuhi setiap bulannya sebesar Rp. 1,250,000.00 dan Jumlah maksimal yang belanja kerdit yang disediakan oleh Mini market Koperasi Rp. 1,200,000.00.

Bentuk partisipasi anggota sebagai pengguna Unit Mini Market adalah dengan cara memanfaatkan apa yang disediakan dan ditawarkan oleh Unit Mini Market yang dikelola oleh pengurus dan karyawan koperasi, terdapat fenomena yang diduga mempengaruhi tinggi rendahnya tingkat partisipasi anggota dalam pemanfaatan pelayanan yang disediakan oleh koperasi pada unit mini market yaitu Strategi Bauran Pemasaran yang tidak tepat, berdasarkan pendapat dari Philip Kotler $(2005 ; 17)$ Bauran Pemasaran (Marketing Mix) memiliki empat variabel yang dapat mempengaruhi saluran perdagangan dan konsumen akhir, Keempat variabel tersebut adalah produk,harga,tempat dan promosi serta berdasarkan pendapat Tjiptono \& Chandra $(2012 ; 72)$ dalam kaitannya dengan kualitas pelayanan terdapat lima dimensi pokok yaitu Realibilitas,Responsivitas,Jaminan,Empati serta bukti fisik (Tangibels). Pada gambar 1.1 dapat diduga bahwa jumlah biaya yang dikeluarkan anggota setiap bulannya untuk belanja di mini market koperasi rendah dapat diartikan sebagai tingkat partisipasi anggota rendah dengan tidak memanfaatkan pelayanan yang diberikan koperasi secara maksimal.

Untuk mengetahui dengan jelas tentang penyebab dari masalah tersebut, apakah terdapat dampak pelaksanaan strategi bauran pemasaran dan kualitas pelayanan terhadap tingkat partisipasi anggota sebagai pengguna dalam pemanfaatan pelayanan koperasi pada Unit Mini Market Koperasi Karyawan "Karya Sejahtera", Hal ini penting untuk dilakukan agar dapat dicari dan diketahui solusinya dengan cara menentukan upaya-upaya manajerial yang tepat pada Unit Mini Market yang nantinya diharapkan dapat meningkatkan partisipasi anggota sebagai pengguna dalam pemanfaatan pelayanan yang diberikan oleh koperasi.

\section{Rumusan Masalah}

Berdasarkan uraian yang terdapat pada latar belakang penelitian, maka permasalahan yang akan dibahas dalam penelitian ini dapat diidentifikasikan hal-hal sebagai berikut:

1) Bagaimana Dampak Strategi Bauran Pemasaran erhadap tingkat partisipasi anggota sebagai pengguna pada Mini Market Koperasi Karyawan "Karya Sejahtera".

2) Bagaimana Dampak Kualitas Pelayanan terhadap tingkat partisipasi anggota sebagai pengguna pada Mini Market Koperasi Karyawan "Karya Sejahtera".

3) Bagaimana Dampak Strategi Bauran Pemasaran dan Kualitas Pelayanan terhadap Tingkat 
Partisipasi anggota sebagai pengguna pada Mini Market Koperasi Karyawan "Karya Sejahtera".

4) Bagaimana upaya-upaya manajerial yang perlu dilakukanan pada Mini Market Koperasi Karyawan Karya Sejahtera berkaitan dengan Startegi Bauran Pemasaran dan Kualitas Pelayanan dalam meningkatkan Partisipasi anggota sebagai pengguna agar pemanfaatan pelayanan yang diberikan oleh koperasi di masa yang akan datang terus meningkat.

\section{Maksud dan Tujuan Penelitian}

1) Untuk mengetahui Dampak Strategi Bauran Pemasaran terhadap Tingkat Partisipasi Anggota sebagai pengguna pada Mini Market Koperasi Karyawan "Karya Sejahtera".

2) Untuk mengetahui Dampak Kualitas Pelayanan terhadapt Tingkat \Partisipasi Anggota sebagai pengguna pada Mini Market Karya Sejahtera

3) Untuk mengetahui Dampak Strategi Bauran Pemasaran dan Kualitas Pelayanan terhadap Tingkat Partisipasi Anggota sebagai pengguna pada Mini Market Koperasi Karyawan "Karya Sejahtera”.

4) Untuk menentukan upaya-upaya manajerial yang harus dilakukan oleh Mini Market Koperasi Karyawan "Karya Sejahtera" dalam upaya meningkatkan Partisipasi Anggota sebagai pengguna koperasi.

\section{Kegunaan Penelitian}

Hasil penelitian ini diharapkan dapat memberikan manfaat baik bagi aspek guna laksana maupun bagi pengembangan ilmu pengetahuan diantaranya sebagai berikut:

\section{1) Aspek Guna Laksana}

Bagi koperasi yang diteliti, diharapkan hasil penelitian ini dapat digunakan untuk bahan pertimbangan dalam menetapkan kebijakan dan pengambilan keputusan, khususnya yang berhubungan dengan upaya-upaya peningkatan partisipasi anggota pada Mini Market Koperasi Karyawan "Karya Sejahtera" dan bagi ilmu pengetahuan, penelitian ini diharapanan dapat memberikan sumbangan ilmu pengetahuan.

2) Aspek Pengembangan ilmu Pengetahuan

Bagi peneliti, penelitian ini dapat menambah wawasan dan pengetahuan tentang koperasi baik secara teori maupun aplikasinya di lapangan dan bagi peneliti lain, penelitian ini dapat digunakan sebagai bahan perbandingan dan pegangan bagi penelitian-penelitian lebih lanjut yang akan dilaksanakan.

\section{TINJAUAN PUSTAKA}

\section{Koperasi}

Koperasi sebagai suatu badan usaha yang mempunyai anggota yang terdiri dari orang atau badan hukum koperasi, koperasi juga merupakan lembaga ekonomi baagi anggota serta masyarakat disekitarnya, anggota tersebut mempunyai kepentingan yang sama dalam mendapatkan manfaat ekonomi yang sebesar besarnya.

Secara umum koperasi dipahmi sebagai perkumpulan orang yang secara sukarela mempersatukan diri untuk memperjuangkan peningkatan kesejahteraan ekonomi para anggota,menurut Revrisond Baswir (2000;3) beberapa pokok pikiran yang dapat ditarik dari uraian mengenai pengertian koperasi adalah sebagai berikut:

1) Koperasi adalah suatu perkumpulan yang didirikan oleh orang-orang yang memiliki kemampuan ekonomi terbatas, yang bertujuan untuk memperjuangkan peningkatan kesejahteraan ekonomi anggota.

2) Bentuk kerjasama dalam koperasi bersifat sukarela

3) Masing-masing anggota koperasi mempunyai hak dan kewajiban yang sama

4) Masing-masing anggota koperasi berkewajiban untuk mengembangkan serta mengawasi jalannya usaha koperasi

5) Risiko dan keuntungan usaha koperasi ditanggung dan dibagi secara adil.

Pada perusahaan atau didalam suatu badan usaha ujung tombaknya adalah bagian pemasaran, pemasaran ini jugalah yang akan menggerkan keberhasilan fungsi-fungsi perusaaan lainnya, demikian juga sebaliknya jika pemasaran suatu badan usaha atau perusahaan gagal, maka kegagalan ini akan dirasakan oleh semua fungsi perusahaan yang ada, bahkan akan melumpuhkan kegiatan usaha perusahaan, hal ini dapat dipahami mengingat bahwa pemasaran merupakan satu satunya bagian di perusahaan yang menghasilkan pendapatan.

Menurut Ramudi Arifin ( 2013;64) dikenal juga istilah koperasi Single Purpose dan Multi Purpose yang pengertiannya adalah sebagai berikut

4. Koperasi Tunggal Usaha (Single Purpose), adalah koperasi yang menggunakan hanya satu macam kesempatan untuk memperluas usaha

5. Koperasi Serba Usaha (Multy Purpose), adalah koperasi yang menyelenggarakan usaha lebih dari satu macam kebutuhan ekonomi atau kepentingan ekonomi para anggotanya. 


\section{Bauran Pemasaran}

Menurut Philip Kotler $(2005 ; 17)$ "Bauran pemasaran adalah seperangkat alat pemasaran yang digunakan perusahaan untuk terus menerus mencapai tujuan pemasarannya dalam pasar sasaran.” Bauaran pemasaran harus terus menerus digunakan untuk mencapai tujuan pemasaran di pasar sasaran, pasar sasaran adalah dimana perusahaan memutuskan segmen mana yang memperlihatkan peluang paling besar.

Bauran pemasaran (marketing mix) memiliki empat variabel yang dapat mempengaruhi saluran perdagangan dan konsumen akhir. Keempat variabel tersebut adalah sebagai berikut:

1) Produk

Merupakan sekumpulan atribut yang nyata dan tidak nyata. Menurut Philip Kotler $(2005 ; 17)$ produk adalah : "penawaran yang berwujud dari perusahaan kepada pasar yang mencakup keragaman produk, kualitas produk design merk, kemasan, ukuran,pelayanan, garansi dan imbalan."

2) Harga

Harga merupakan nilai yang ada pada suatu produk yang dibutuhkan untuk mendaptkan produk dan pelayanan yang menyertainya. Maka dengan adanya harga diharpakan dicapainya laba (profit) yang tentunya dapat dicapai dengan dengan tingkatan harga tertentu yang sesuai dengan harapan yang ingin dicapai. Harga sering digunakan sebagai alat kompetitif, bahkan dapat dikatakan bahwa persaingan harga yang ketat kadang-kadang dapat menyebabkan perang harga (price war). Harga juga dapat membantu membentuk citra sebuah produk.

Pada koperasi penetapan harga sangat penting sekali peranannya dimana harga ditetapkan berbeda antara anggota dan non-anggota, hal ini dilakukan karena dalam koperasi tujuan utama adalah untuk memenuhi kebutuhan anggota sebagai pelanggan (customer need and want), setelah anggota tercukupi atau terpuaskan baru langkah selanjutnya koperasi membidik sasaran non-anggota.

\section{3) Tempat atau Distribusi}

Tempat merupakan suatu sarana perpindahan produk yang dihasilkan produsen kepada konsumen akhir, sehingga perpindahan produk yang diharapkan dapat menciptakan adanya kecepatan dan ketepatan waktu. Pada dasarnya tempat yang baik dalam pemasaran adalah tempat yang mudah dijangkau oleh konsumen dan perusahaanpun mudah dalam membawa produknya kepada konsumen, mudah dalam distribusi barang dan nyaman bagi konsumen dalam proses pembelian.

4) Promosi

Promosi, adalah meliputi semua kegiatan yang dilakukan perusahaan untuk mengkomunikasikan dan mempromosikan produknya kepada pasar sasaran. Promosi merupakan salah satu cara untuk menyapiakan informasi suatu produk melalui kombinasi periklanan, personal selling, promosi penjualan dan publisitasnya

\section{Kualitas Pelayanan}

Kualitas adalah suatu kondisi dinamis yang berhubungan dengan produk,jasa,manusia, proses dan lingkungan yang memenuhi dan memilikiharapan, Tjiptono (2008:51), Kualitas Pelayanan menurut J. Supranto (2006:226) adalah kata bagi penyedia jasa merupakan sesuatu yang harus dikerjakan dengan baik, sedangkan defenisi pelayanan Gromroos adalah suatu aktivitas atau serangkaian aktivitas yang bersifat tidak kasat mata yang terjadi sebagai akibat adanya interaksi antara konsumen dengan karyawan atau hal-hal lain yang disediakan oleh perusahaan pemebri layanan yang dimaksud untuk memecahkan permasalahan konsumen/pelanggan (Ratminto, 2005:2) dalam hal ini perusahaan adalah perusahaan koperasi.

Dimensi kualitas pelayanan dibagi menjadi lima dimensi diantaranya adalah (Lupiyoadi, 2001:148):

1) Tangibles (bukti fisik) yaitu kemampuan suatu perusahaan dalam menunjukkan eksistensinya kepada pihak eksternal.

2) Reliability (kehandalan) yaitu kemampuan perusahaan untuk memberikan pelayanan sesuai yang dijanjikan secara akurat dan terpercaya.

3) Responsiveness (ketanggapan) yaitu kemauan untuk membantu dan memberikan pelayanan yang cepat (responsif) dan tepat kepada pelanggan, dengan penyampaian informasi yang jelas.

4) Assurance (jaminan dan kepastian) yaitu pengetahuan, kesopansantunan, dan kemampuan para pegawai perusahaan untuk menumbuhkan rasa percaya para pelanggan kepada perusahaan.

5) Emphaty (empati) yaitu memberikan perhatian yang tulus dan brsifat individual atau pribadi yang diberikan kepada para pelanggan dengan berupaya memahami keinginan konsumen. 


\section{Partisipasi Anggota Koperasi}

Menurut Ramudi Arifin (2006;53) partisipasi anggota didefinisikan sebagai berikut : "Partisipasi anggota adalah keterlibatan anggota didalam organisasi dan perusahaan koperasi baik didalam kedudukannya sebagi pemilik maupun sebagai pelanggan"

Menurut Ramudi Arifin $(2013 ; 28)$ peranan anggota dalam kegiatan koperasi dapat dibedakan:

1) Peranan anggota dalam kedudukan sebagai pemilik adalah :

a) Memberikan kontribusinya terhadap pembentukan dan pertumbuhan perusahaan koperasi dalam bentuk kontribusi keuangan melalui penyertaan modal, pembentukan cadangan, simpanan dan melalui usaha-usaha pribadinya.

b) Mengambil bagian dalam penetapan tujuan, pembuatan keputusan dan dalam proses pengawasan tata kehidupan koperasinya.

2) Peranan anggota dalam kedudukan sebagi pelanggan atau pengguna adalah dengan memanfaatkan berbagi produk dan jasa yang disediakan oleh perusahaan koperasi dalam menunjang kepentingan-kepentingannya.

\section{Partisipasi Anggota Sebagai Pemilik}

Sebagai pemilik, anggota dapat menentukan arah organisasi koperasi, hal ini dikarenakan dalam koperasi, Rapat anggota Tahunan merupakan kekuasaan tertinggi. Setiap anggota mempunyai kedudukan yang sama serta hak yang sama antara anggota yang satu dengan yang lain yang dibuktikan dengan prinsif one man, one vote, one voice dalam pelaksaanaan Rapat Anggota.

Menurut Ramudi Arifin (2006;56) bahwa anggota sebagai pemilik koperasi mempunyai kewajiban sebagai berikut :

1) Merumuskan tujuan koperasi agar sesuai dengan keinginan anggota

2) Menetapkan program kerja koperasi sebagai wujud dari langkah-langkah yang harus ditempuh koperasi, sesuai dengan tujuan yang dirumuskan.

3) Memodali dan membiayai koperasi agar program-program yang telah ditetapkan dapat dilaksanakan oleh manajemen koperasi

4) Mengawasi jalannya koperasi agar selalu berdasar pada jalur norma,nilai, prinsip, program kerja dan keputusan-keputusan rapat anggota.

\section{Partisipasi Anggota Sebagai Pelanggan/ Pengguna}

Partisipasi anggota sebagai pengguna dapat diukur dari kesediaan anggota untuk memikul kewajiban dan hak keanggotaan secara bertanggungjawab. Jika sebagian besar anggota sudah menunaikan kewajiban dan melaksanakan hak secara bertanggungjawab dan memanfaatkan koperasi untuk memenuhi kebutuhan ekonominya, maka partisipasi anggota koperasi yang bersangkutan sudah dikatakan baik, akan tetapi jika ternyata hanya sedikit yang demikian, maka partisipasi anggota koperasi yang dimaksud dikatakan buruk atau rendah, Koperasi akan berfungsi dengan baik dan berhasil jika mengikut sertakan partisipasi anggota, tanpa adanya partisipasi anggota mustahil koperasi dapat berhasil dengan baik

\section{HASIL DAN PEMBAHASAN}

\section{Hasil Penelitian}

Hasil penelitian ini melipuyi berbagai aspek, mulai dari diskripsi responden serta diskripsi setiap variabel yang dijadikan objek penelitian yang meliputi

1) Variabel srategi bauran pemasaran terdiri dari produk, harga, promosi dan distribusi

2) Variabel kulaitas pelayanan terdiri dari reliabilitas, responsivitas, asurance, emphaty dan tangibels

3) Variabel partisipasi anggota yaitu kesikutsertaan anggota koperasi dalam transaksi pembelian di mini market.

\section{Deskripsi Responden}

Penelitian ini menyebarkan 97 kuisioner kepada anggota koperasi karya sejahtera, kuisioner terdiri dari tiga bagian yaitu tanggapan mengenai startegi bauran pemasaran, kualitas pelayanan dan tingkat partisipasi anggota sebagai pengguna koperasi.

\section{Deskripsi Variabel Penelitian}

\section{Tanggapan Responden Terhadap Strategi Bauran Pemasaran Mini Market Koperasi Karya Sejahtera}

Untuk mengetahui tanggapan responden terhadap Startegi Bauran Pemasaran, peneliti menganalisis data kuisioner dari 14 pernyataan yang di jawab oleh 97 responden dengan alternatif jawaban Sangat Setuju (SS), Setuju (S), Kurang Setuju (KS), Tidak Setuju (TS), Sangat Tidak Setuju (STS). Selanjutnya hasil jawaban responden dikumulatifkan menjadi nilai skor dan dipersentase seperti terlihat pada tabel 3.1 berikut ini: 
Tabel 2. Jawaban Responden Terhadap Strategi Bauran Pemasaran

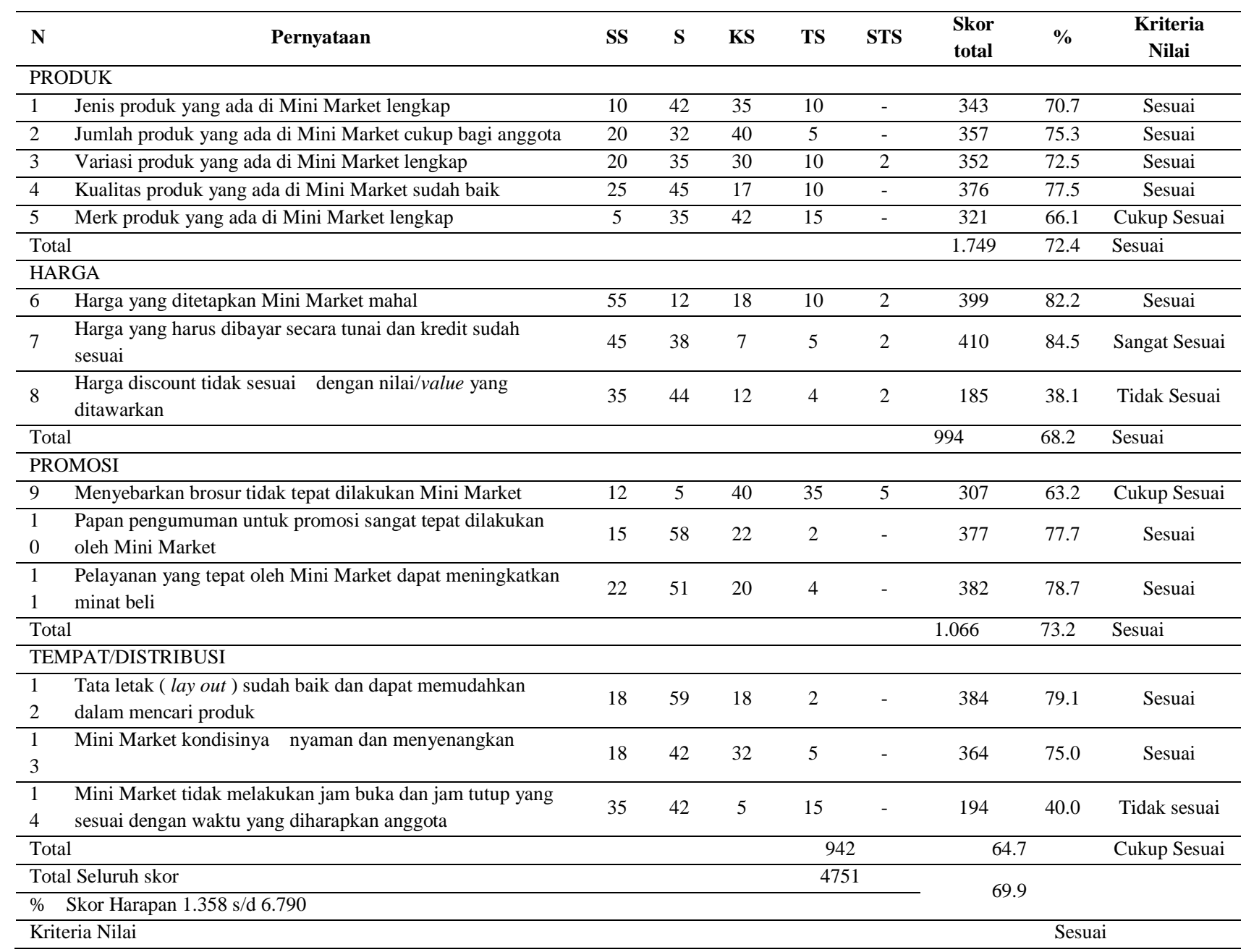

Sumber : Data Primer yang diolah, 2016

Tanggapan Responden Terhadap Kualitas Pelayanan Mini Market Koperasi Karya Sejahtera

Tabel 3. Jawaban Responden Tentang Variabel Kualitas Pelayanan

\begin{tabular}{|c|c|c|c|c|c|c|c|c|c|}
\hline No. & Pernyataan & SS & $\mathbf{S}$ & KS & TS & STS & $\begin{array}{l}\text { Skor } \\
\text { Total }\end{array}$ & $\%$ & Kriteria Nilai \\
\hline \multicolumn{10}{|c|}{ REALIBILITAS } \\
\hline 1 & $\begin{array}{l}\text { Cekatan dan segera dalam menangani } \\
\text { kebutuahn anggota }\end{array}$ & 4 & 40 & 51 & 2 & - & 337 & 69.9 & Baik \\
\hline 2 & $\begin{array}{l}\text { Akurat dalam perhitungan administrasi pada } \\
\text { saat anggota membayar tunai atau kred }\end{array}$ & 35 & 52 & 8 & 2 & - & 411 & 84.7 & Sangat Baik \\
\hline 3 & $\begin{array}{l}\text { Memberikan perhatian serius dan layanan } \\
\text { memuaskan pada saat anggota menyampaikan } \\
\text { keluhan/ketidak nyamanan }\end{array}$ & 15 & 65 & 17 & - & - & 386 & 79.5 & Baik \\
\hline Total & & & & & & & 1.134 & 78.0 & Baik \\
\hline \multicolumn{10}{|c|}{ RESPONSIVITAS } \\
\hline 4 & $\begin{array}{l}\text { Selalu membantu setiap ada anggota yang } \\
\text { kesulitan dalam mencari kebutuhannya }\end{array}$ & 44 & 51 & 2 & - & - & 430 & 88.6 & Sangat Baik \\
\hline 5 & $\begin{array}{l}\text { Cepat tanggap ketika anggota } \\
\text { memmebutuhkan bantuaan }\end{array}$ & 40 & 42 & 15 & - & - & 413 & 85.1 & Sangat Baik \\
\hline 6 & $\begin{array}{l}\text { Mini Market tidak memiliki karyawan yang } \\
\text { manpu dan paham tentang produk-produk } \\
\text { yang tersedia }\end{array}$ & 15 & 35 & 17 & 24 & 6 & 262 & 54.0 & Cukup Baik \\
\hline Total & & & & & & & 1.105 & 75.9 & Baik \\
\hline
\end{tabular}




\begin{tabular}{|c|c|c|c|c|c|c|c|c|c|}
\hline No. & Pernyataan & SS & $\mathbf{S}$ & KS & TS & STS & $\begin{array}{l}\text { Skor } \\
\text { Total }\end{array}$ & $\%$ & Kriteria Nilai \\
\hline \multicolumn{10}{|c|}{ JAMINAN } \\
\hline 7 & $\begin{array}{l}\text { Memiliki karyawan yang selalu bersikap } \\
\text { sopan dan sabar terhadap anggota }\end{array}$ & 15 & 45 & 22 & 10 & 5 & 346 & 71.3 & Baik \\
\hline 8 & $\begin{array}{l}\text { Memiliki karyawan yang bersikap jujur dan } \\
\text { terbuka dalam memberikan pelayanan } \\
\text { terhadap anggota }\end{array}$ & 12 & 52 & 25 & 5 & 3 & 356 & 73.4 & Baik \\
\hline Total & & & & & & & 702 & 72.3 & Baik \\
\hline \multicolumn{10}{|c|}{ EMPATI } \\
\hline 9 & $\begin{array}{l}\text { Memiliki karyawan yang dapat } \\
\text { berkomunikasi dengan baik terhadap anggota }\end{array}$ & 27 & 58 & 12 & - & - & 403 & 83.0 & Baik \\
\hline 10 & $\begin{array}{l}\text { Memberikan perhatian individual kepada } \\
\text { anggota yang mendapatakan kesulitan di mini } \\
\text { market }\end{array}$ & 5 & 44 & 40 & 5 & 3 & 334 & 68.8 & $\begin{array}{l}\text { Cukup } \\
\text { Baik }\end{array}$ \\
\hline 11 & $\begin{array}{l}\text { Tidak melakukan pelayanan yang sama dan } \\
\text { memandang status sosial terhadap anggota }\end{array}$ & 2 & 12 & 58 & 20 & 5 & 305 & 62.8 & Cukup Baik \\
\hline Total & & & & & & & 1.042 & 71.5 & Baik \\
\hline \multicolumn{10}{|c|}{ BUKTI FISIK ( TANGIBLES) } \\
\hline 12 & $\begin{array}{l}\text { Mini Market ruangannya bersih, nyaman dan } \\
\text { memiliki tata ruang yang menarik }\end{array}$ & 25 & 59 & 10 & 3 & - & 397 & 81.8 & Baik \\
\hline 13 & $\begin{array}{l}\text { Fasilitas pelengkap yang disediakan ( tas } \\
\text { belanja. Ruangan sejuk, kursi tempat duduk ) } \\
\text { bersih dan dalam keadaan baik }\end{array}$ & 22 & 57 & 11 & 7 & - & 385 & 79.3 & Baik \\
\hline 14 & $\begin{array}{l}\text { Memiliki karyawan yang jumlahnya cukup, } \\
\text { bersih dan rapih }\end{array}$ & 15 & 65 & 11 & 6 & - & 350 & 72.1 & Baik \\
\hline Total & & & & & & & 1.132 & 77.7 & Baik \\
\hline Total & & & & & & & 5115 & & \\
\hline$\%$ ber & asarkan Skor Harapan $1.358 \mathrm{~s} / \mathrm{d} 6.790$ & & & & & & & 75.3 & \\
\hline Kriter & Nilai & & & & & & & & Baik \\
\hline
\end{tabular}

Tanggapan Responden Terhadap Tingkat Partisipasi Anggota Sebagai Pengguna Mini Market Koperasi Karya Sejahtera

Tabel 4. Jumlah Skor dan Persentase Tingkat Partisipasi Anggota Sebagai Pengguna Koperasi

\begin{tabular}{|c|c|c|c|c|c|c|c|c|c|}
\hline No & Pernyataan & SS & $\mathbf{S}$ & KS & TS & STS & $\begin{array}{l}\text { Skor } \\
\text { Total }\end{array}$ & $\%$ & $\begin{array}{c}\text { Kriteria } \\
\text { Nilai }\end{array}$ \\
\hline \multicolumn{10}{|c|}{ KEIKUTSERTAAN ANGGOTA DALAM PEMBELIAN DI MINI MARKET } \\
\hline 1 & $\begin{array}{l}\text { Atas kesadaran sendiri anggota melakukan } \\
\text { kunjungan ke Mini Market sebagai bentuk } \\
\text { partisipasi }\end{array}$ & 5 & 25 & 58 & 9 & - & 317 & 65.3 & $\begin{array}{l}\text { Cukup } \\
\text { Tinggi }\end{array}$ \\
\hline 2 & $\begin{array}{l}\text { Untuk membeli produk di Mini Market } \\
\text { anggota membelanjakan uangnya secara tunai } \\
\text { dan kredit }\end{array}$ & 25 & 72 & - & - & - & 413 & 85.1 & $\begin{array}{l}\text { Sangat } \\
\text { Tinggi }\end{array}$ \\
\hline 3 & $\begin{array}{l}\text { Anggota beranggapan bahwa belanja di Mini } \\
\text { Market lebih menguntungkan dari pada di } \\
\text { tempat lain }\end{array}$ & 5 & 22 & 62 & 8 & - & 315 & 64.9 & $\begin{array}{l}\text { Cukup } \\
\text { Tinggi }\end{array}$ \\
\hline 4 & $\begin{array}{l}\text { Kontraksional/kouta kredit di mini market } \\
\text { setiap bulan di gunakan seluruhnya oleh } \\
\text { anggota }\end{array}$ & 15 & 40 & 41 & 1 & - & 360 & 74.2 & Tinggi \\
\hline 5 & $\begin{array}{l}\text { Kontraksional/kouta kredit di mini market } \\
\text { setiap bulan tidak gunakan oleh anggota }\end{array}$ & 12 & 43 & 38 & 4 & - & 354 & 72.9 & Tinggi \\
\hline 6 & $\begin{array}{l}\text { Selain transaksi kredit sesuai } \\
\text { kontraksional/kouta juga melakukan transaksi }\end{array}$ & 25 & 55 & 33 & - & - & 396 & 81.4 & Tinggi \\
\hline
\end{tabular}




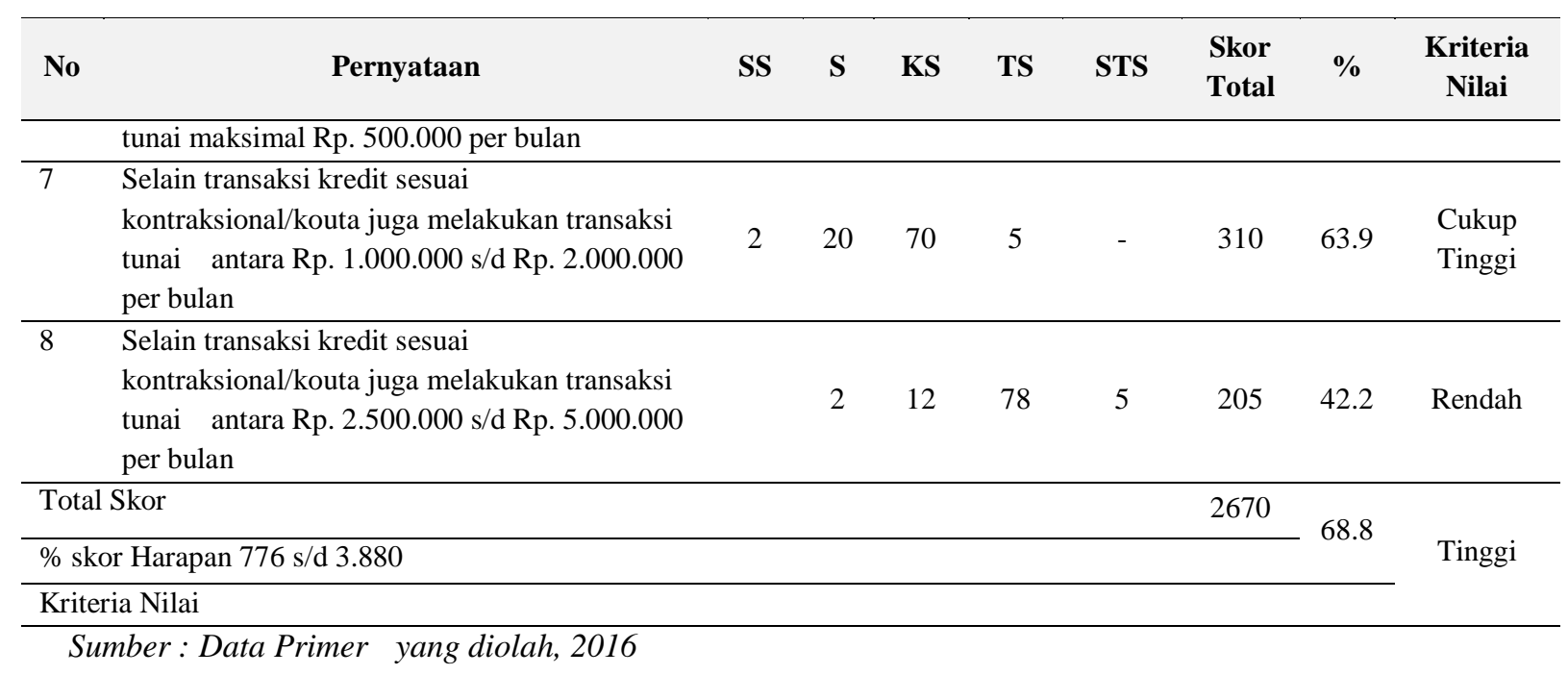

\section{Uji Validitas dan Realibilitas Instrumen Penelitian}

\section{Uji Validitas Strategi Bauran Pemasaran}

Dari 14 item kuisioner pernyataan tentang

Strategi bauran pemasaran yang disebar kepada reponden sebagai sample terpilih, maka dihasilkan dari pengolahan data variabel startegi bauran pemasaran tersebut koefesien korelasi berada diatas 0,3 maka jika dibandingkan semuanya butir istrumen pernyataan dinyatakan valid, butir yang menyatakan validitas teringgi adalah butir 10 dengan nilai koefesien korelasi sebesar 0.733 dan butir terendah adalah butir 6 dengan koefesien korelasi 0.312, untuk itu kuisioner yang digunakan dianggap layak untuk diolah sebagai data penelitian.

\section{Uji Validitas Kualitas Pelayanan}

Dari 14 item kuisioner tentang Kualitas Pelayanan, hasil pengolahan data variabel Kualitas Pelayanan tersebut koefesien korelasi berada diatas 0,3 maka jika dibandingkan semuanya butir istrumen dinyatakan valid, butir yang menyatakan validitas tertinggi adalah butir 14 dengan nilai koefesien korelasi sebesar 0.496 dan butir terendah adalah butir 7 dengan koefesien korelasi 0.322, untuk itu kuisioner yang digunakan layak untuk diolah sebagai data penelitian.

\section{Uji Validitas Instrumen Tingkat Partisipasi Anggota Sebagai pengguna Koperasi}

Dari 8 item kuisioner tentang Tingkat Partisipasi Anggota Sebagai Pengguna Koperasi, hasil pengolahan data variabel kualitas pelayanan tersebut koefesien korelasi berada diatas 0,3 maka jika dibandingkan semuanya butir istrumen dinyatakan valid, butir yang menyatakan validitas tertinggi adalah butir 7 dengan nilai koefesien korelasi sebesar 0.539 dan butir terendah adalah butir 5 dengan koefesien korelasi 0.331, untuk itu kuisioner yang digunakan layak untuk diolah sebagai data penelitian.

\section{Uji Reabilitas Instrumen Strategi Bauran Pemasaran}

Dari 14 item kuisioner Strategi Bauran Pemasaran, variabel tersebut berada diatas 0,7. Yaitu berada pada anggka 0.880 dengan katagori derajat reliabilitas sedang, hubungan cukup berarti, maka jika dibandingkan semuanya reliabel, untuk itu kuesioner yang digunakan layak untuk diolah sebagai data penelitian.

\section{Uji Reabilitas Instrumen Kualitas pelayanan}

Dari 14 item kuisioner Kualitas Pelayanan yang dijawab oleh responden dan data tersebut dioleh mengunakan program SPSS ver 20, diperoleh nilai bahwa variabel kualitas pelayanan tersebut berada diatas 0,7. Yaitu berada pada anggka 0.746, berdasarkan tabel 3.8 klasifikasi tingkat korelasi maka diperoleh katagori derajat reliabilitas sedang dan dengan katogori hubungan cukup berarti, maka jika dibandingkan semuanya butir pernyataan dinyatakan semuanya reliabel, untuk itu kuesioner yang digunakan layak untuk disebar kepada responden sebagai simple terpilih dan data yang diperoleh dapat diolah sebagai data penelitian.

\section{Uji Reabilitas Instrumen Tingkat Partisipasi Anggota sebagai pengguna koperasi}

Dari 8 item kuisioner pernyataan tentang Tingkat Partisipasi Anggota Sebagai Pengguna Koperasi yang disebar kepada responden yang terpilih sebagai sample, hasil dari oleh data menggunkan program SPSS versi 20 variabel Tingkat Partisipasi anggota sebagai pengguna koperasi tersebut berada diatas 0,7 , Yaitu berada pada anggka 0.800 , berdasarkan tabel 3.8 klasifikasi tingkat korelasi maka diperoleh 
katagori derajat reliabilitas sedang, dengan katagori hubungan cukup berarti, maka jika dibandingkan semuanya butir pernyataan dinyatakan semuanya reliabel, untuk itu kuisioner yang digunakan layak untuk disebar kepada responden sebagai sampel terpilih dan data yang diperoleh dapat diolah sebagai data penelitian.

\section{Uji Asumsi Klasik}

\section{Uji Heterokedastisitas}

Hasil pengujian heteroskedastis menunjukan nilai signifikansi variable Strategi Bauran Pemasaran memiliki lebih besar dari 0,05 (sig=0,478), hal ini menunjukan pada variabel Strategi Bauran Pemasaran tidak terjadi gejala heteroskedastis, Pada pengujian heteroskedastis Kualitas Pelayanan memiliki nilai lebih besar dari 0.05 ( $\mathrm{sig}=0,064)$, hal ini menunjukan pada variabel Startegi Bauran Pemasaran tidak terjadi gejala heteroskedastis

\section{Uji Multikolinieritas}

Untuk mendeteksi ada tidaknya multikolinier dalam model yang digunakan dilakukan pengujian VIF. Tahapan untuk menguji multikolinier adalah sebagai berikut:

1) Menentukan Hipotesis

$\mathrm{H}_{0}: \square=0$ artinya pada persamaan yang

digunakan tidak terjadi kolinier

$\mathrm{H}_{1}$ : $\square \square>0$ artinya pada persamaan yang

digunakan terjadi kolinier

2) Mengambil Keputusan

Dasar pengambilan keputusan:

Bila nilai $\square \square \mathrm{VIF}<10$ berarti tidak ada multikolinier. Bila nilai $\square \square$ VIF > 10, berarti ada multikolinier.

3) Menentukan Nilai Multikolinier

Tabel 5 Pengujian Multikolinier

\begin{tabular}{|c|c|c|c|}
\hline Variabel & VIF & $\begin{array}{c}\text { Nilai } \\
\text { Kritis }\end{array}$ & Keputusan \\
\hline $\begin{array}{c}\text { Strategi Bauran } \\
\text { Pemasaran }\end{array}$ & 1,301 & 10 & $\begin{array}{c}\text { Tidak } \\
\text { berkolinier }\end{array}$ \\
\hline $\begin{array}{c}\text { Kualitas } \\
\text { Pelayanan }\end{array}$ & 1,301 & 10 & $\begin{array}{c}\text { Tidak } \\
\text { berkolinier }\end{array}$ \\
\hline
\end{tabular}

\section{Pembahasan}

Dampak Strategi Bauran Pemasaran Terhadap Tingkat Partisipasi Anggota Sebagai Pengguna Koperasi

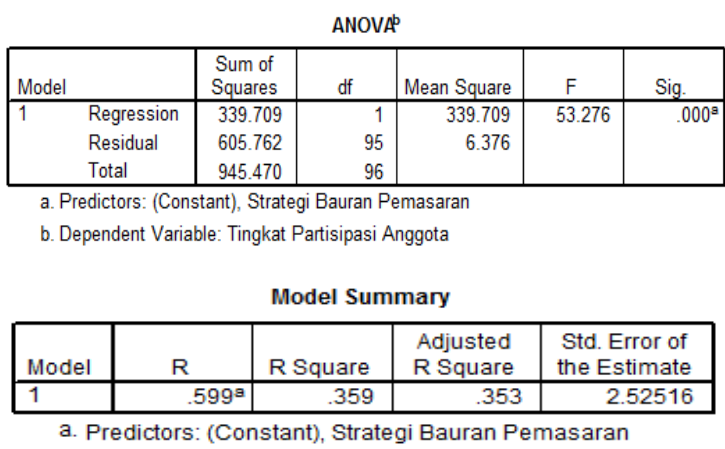

\begin{tabular}{|c|c|c|c|c|c|c|}
\hline \multicolumn{7}{|c|}{ Coefficients $^{a}$} \\
\hline \multirow[b]{2}{*}{ Model } & & \multicolumn{2}{|c|}{$\begin{array}{l}\text { Unstandardized } \\
\text { Coefficients }\end{array}$} & \multirow{2}{*}{$\begin{array}{c}\begin{array}{c}\text { Standardized } \\
\text { Coefficients }\end{array} \\
\text { Beta }\end{array}$} & \multirow[b]{2}{*}{$t$} & \multirow[b]{2}{*}{ Sig. } \\
\hline & & $\mathrm{B}$ & Std. Error & & & \\
\hline 1 & (Constant) & 7.787 & 2.131 & & 3.655 & .000 \\
\hline & $\begin{array}{l}\text { Strategi Bauran } \\
\text { Pemasaran }\end{array}$ & .367 & .050 & .599 & 7.299 & .000 \\
\hline
\end{tabular}

Interprestasi out pengolahan data tersebut di atas adalah jika strategi bauran pemasaran yang diterapkan secara parsial dilaksanakan dengan baik maka tingkat partisipasi anggota sebagai pengguna koperasi akan mengalami peningkatan sebesar 0,367 satu satuan. Sebaliknya jika Strategi Bauran Pemasaran tidak dilaksanakan dengan baik maka Tingkat Partisipasi Anggota akan mengalami penuruanan sebesar 0,367 satu satuan. Selanjutnya untuk mengetahui hubungan dan dampak strategi bauran pemasaran terhadap tingkat partisipasi anggota sebagai pengguna koperasi dapat diliaht dari koefisien korelasi (r) yang menunjukkan hubungan keeratan antar variabel bebas dan variabel terikat. Semakin besar nilai koefisien korelasi semakin erat hubungan variabel bebas dan variabel terikat.

Pada hasil perhitungan dapat ditunjukkan bahwa besarnya nilai koefisien korelasi untuk persamaan yang dibahas yaitu sebesar 0.599 Ini berarti berdasarkan tabel 3.9 interval koefesien koerelasi dinyatakan bahwa adanya hubungan yang cukup erat antara variabel bebas dengan variabel terikat karena semakin mendekati satu. Untuk melihat perubahan setiap variabel dinyatakan dalam koefesien determinasi $\left(\mathrm{R}^{2)}\right.$.

Dari hasil perhitungan bahwa koefisien determinasi $\left(\mathrm{R}^{2}\right)$ sebesar 0,359. Ini berarti variasi perubahan variabel terikat sebesar $35,9 \%$ dipengaruhi oleh variasi perubahan variabel bebas dan sisanya sebesar $\quad 64,1 \%$ dipengaruhi oleh faktor lain di luar model. 
Dampak Kualitas Pelayanan Terhadap Tingkat Partisipasi Anggota Sebagai Pengguna Koperasi

\begin{tabular}{|c|c|c|c|c|c|c|}
\hline \multicolumn{7}{|c|}{$A N O V A^{b}$} \\
\hline Model & & $\begin{array}{l}\text { Sum of } \\
\text { Squares }\end{array}$ & df & Mean Square & $\mathrm{F}$ & Sig. \\
\hline 1 & Regression & 149.912 & 1 & 149.912 & 17.901 & $.000^{\mathrm{B}}$ \\
\hline & Residual & 795.559 & 95 & 8.374 & & \\
\hline & Total & 945.470 & 96 & & & \\
\hline
\end{tabular}

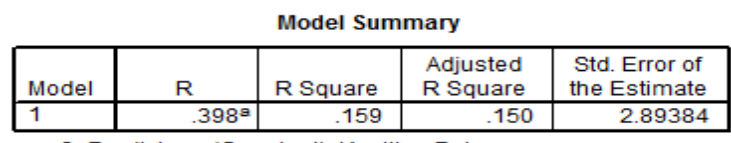

a. Predictors: (Constant), Kualitas Pelayanan

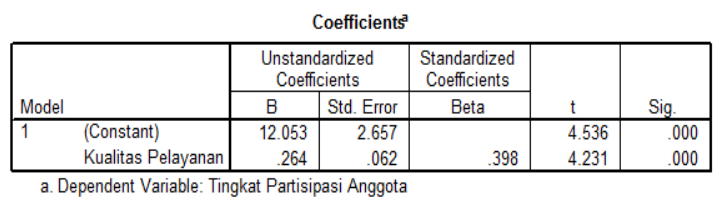

Interprestasi output data tersebut di atas adalah jika Kualitas Pelayanan yang diterapkan secara parsial dilaksanakan dengan baik maka Tingkat Partisipasi Anggota sebagai pengguna koperasi akan mengalami peningkatan sebesar 0,264 satu satuan. Dan sebaliknya jika Kualitas Pelayanan tidak dilaksanakan dengan baik maka Tingkat Partisipasi Anggota akan mengalami penurunan sebesar 0, 264 satu satuan. Selanjutnya untuk mengetahui hubungan dan dampak kualitas pelayanan terhadap tingkat partisipasi anggota sebagai pengguna koperasi maka olah data denag menghitung Koefisien Korelasi (r) yang menunjukkan hubungan keeratan antar variabel bebas dan variabel terikat. Semakin besar nilai koefisien korelasi semakin erat hubungan variabel bebas dan variabel terikat. Pada hasil perhitungan dapat ditunjukkan bahwa besarnya nilai koefisien korelasi untuk persamaan yang dibahas yaitu sebesar 0.398 Ini berarti berdasarkan interval koefesien koerelasi adanya hubungan yang rendah ( tidak kuat) antara variabel bebas dengan variabel terikat karena semakin mendekati nol.

Selanjutnya untuk mengetahi berapa besar pengaruh dilakukan pengujian koefesien determinasi Dari hasil perhitungan bahwa koefisien determinasi $\left(R^{2}\right)$ sebesar 0,159 . Ini berarti variasi perubahan variabel terikat sebesar $15,9 \%$ dipengaruhi oleh variasi perubahan variabel bebas dan sisanya sebesar $84,1 \%$ dipengaruhi oleh faktor lain di luar model.
Dampak Strategi Bauran Pemasaran dan Kualitas Pelayanan terhadap Tingkat Partisipasi Anggota sebagai pengguna koperasi
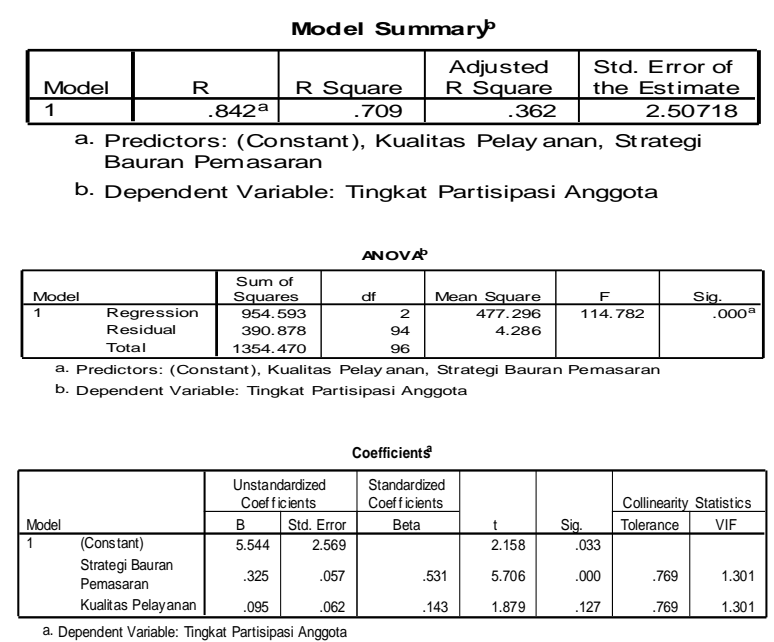

Interprestasi out put data tersebut di atas adalah:

1) Jika Strategi Bauran Pemasaran yang diterapkan dan dilaksanakan dengan baik maka Tingkat Partisipasi Anggota sebagai pengguna Koperasi akan mengalami peningkatan sebesar 0,325 satu satuan. Dan sebaliknya jika Strategi Bauran Pemasaran tidak dilaksanakan dengan baik maka Tingkat Partisipasi Anggota sebagai Pengguna Koperasi akan mengalami penurunan sebesar 0,325 satu satuan dengan asumsi ceteris paribus.

2) Jika Kualitas Pelayanan mengalami peningkatan maka Tingkat Partisipasi Anggota Sebagai Pengguna Koperasi akan mengalami peningkatan sebesar 0,095 satu satuan. Dan sebaliknya jika Kualitas Pelayanan tidak mengalami peningkatan maka Tingkat Partisipasi Anggota Sebagai Pengguna Koperasi akan mengalami penurunan sebesar 0,095 satu satuan.

Selanjutnya untuk mengetahui hubungan dan dampak strategi bauran pemasaran dan kualitas pelayanan terhadap tingkat partisipasi anggota sebagai pengguna koperasi maka dilakukan bebarapa uji koefesien korelasi (r) menunjukan hubungan keeratan antara variabel bebas dan variabel terikat, semakin besar nilai koefesien korelasi semakin erat hubungan variabel bebas dan variabel terikat.

Pada hasil perhitungan dapat ditunjukan bahwa besarnya nilai koefesien korelasi untuk persamaan yang dibahas yaitu sebesar 0.842 ini berarti berdasarkan tabel 3.9 Interval Koefesien Koeralasi adanya hubungan yang sangat erat/kuat antara variabel bebas dengan variabel terikat karena semakain mendekti satu.

Selanjutnya dilakukan perhitungan koefesien Dterminasi, hasil perhitungan bahwa koefisien determinasi $\left(\mathrm{R}^{2}\right)$ sebesar 0,709 . Ini berarti variasi 
perubahan variabel terikat sebesar 70,9\% dipengaruhi oleh variasi perubahan variabel bebas dan sisanya sebesar $29,1 \%$ dipengaruhi oleh faktor lain di luar model.

\section{Upaya-Upaya Manajerial Yang Perlu Dilakukan Untuk Meningkatkan Partisipasi Anggota Sebagai Pengguna Koperasi Melalui Strategi Bauran Pemasaran dan Kualitas Pelayanan}

Upaya-upaya yang perlu dilakukan oleh Koperasi Karyawan Karya Sejahtera PT. Polyfin Canggih dalam meningkatkan Tingkat Partisipasi Anggota Sebagai Pengguna Koperasi yaitu :

1) Dalam Hal Strategi Bauran Pemasaran

a) Produk (jenis produk, jumlah produk, variasi produk,kualitas produk, merk produk) oleh responden dinilai telah sesuai namun hal tersebut dapat didilaksanakan berdasarkan keinginan anggota koperasi melalui rapat anggota tahunan koperasi

b) Harga (harga yang ditetapkan, cara pembayaran, potongan harga) responden menyatakan telah sesuai untuk itu keiputuskan dan penetapannyta harus dilakukan oleh pengurus berdasarkan persetujuan anggota.

c) Promosi (brosur, papan pengumuman, pelayanan karyawan) responden menyatakan telah sesui namum pada pelaksanaannya disesuaikan dengan kebijakan perusahaan karena keberadaan koperasi berada di area perusaan sehingga tepat sasaran.

d) Distribusi/tempat (lay out, perlengkapan dan jumlah karyawan) walaupun responden menyatakan telah sesuai akan tetapai supaya ditinjau ulang secara berkala sehingga anggota merasakan keberadaan koperasi nyaman dan memberi manfaat yang sebaik-baiknya terhadap anggota.

2) Dalam Hal Kualitas Pelayanan

a) Reliabilitas (layanan segera,layanan akurat, layanan memuaskan) responden menyatakan baik agar pelayanan ini tetap baik maka koperasi dapat menggunakan system pengadaan dan penjualan secara komputerisasi yang menyeluruh.

b) Responsivitas (membantu pembeli, cepat tanggap dan karyawan yang kurang paham terhadap produk yang tersedia) dinyatakan oleh responden sudah baik agar penilaian baik ini dapat dipertahankan koperasi dapat memberikan pengarahan dan bimbingan motivasi kepada karyawan koperasi oleh pengurus dan manager koperasi

c) Jaminan (kesopanan, kejujuran) dinilai oleh responden baik, jaminan ini dapat bertahan jika secara berkala memberikan pelatihan dan bimbingan keperibadian dalam meningkatkan kualitas kerja dan mentalitas karyawan koperasi

d) Empati (komunikasi efektif, perhatian personal, pemahaman kebutuhan konsumen) dinilai oleh responden baik untuk mempertahankan penilaian ini yang dapat dilakukan koperasi adalah memberikan kepuasan kepada pelanggan yang melakukan transaksi di koperasi

e) Tangibles (bukti fisik, sarana lengkap dan jumlah karyawan yang cukup) dinilai sudah baik oleh responden, untuk meningkatkannya koperasi supaya melakukan perawatan sarana fisik koperasi dan menambah karyawan koperasi bila intesitas pekerjaan meningkat.

Dengan upaya-upaya tersebut diharapkan tingkat partisipasi anggota sebagai pengguna koperasi dapat meningkat, sehingga tujuan utama atas keberadaan koperasi di lingkungan preusan untuk meningkatkan kesejahteraan ekonomi para anggota koperasi dapat tercapai dan dirasakan manfaatnya secara langsung oleh seluruh anggota koperasi yang merupakan bagian dari karyawan perusahaan.

\section{KESIMPULAN DAN SARAN}

\section{Kesimpulan}

Berdasarkan hasil analisis data yang telah dilakukan terhadap seluruh data yang diperoleh, maka dapat ditarik simpulan sebagai berikut :

1) Strategi Bauran Pemasaran yang meliputi Produk,Harga,Promosi dan Distribusi secara parsial berdampak positif terhadap Tingkat Partisipasi Anggota sebagai Pengguna Koperasi dan dinyakan oleh responden telah sesuai penerapannya di unit mini markept koperasi karya sejahtera, terdapat Indikator yang memperoleh persentase tertinggi dari penilaian responden yaitu bahwa harga produk yang ditawarakan mini market koperasi mahal dan indikator bahwa harga yang harus dibayar secara tunai dan kredit sudah sesuai.

2) Kualitas Pelayanan yang meliputi Reliabilitas, Responsivitas,Jaminan,Empati dan Tangibles secara parsial berdampak positif terhadap Tingkat Partisipasi Anggota sebagai Pengguna Koperasi, dan reponden menyatakan bahwa kualitas pelayanan dinilai baik pada unit mini market koperasi karya sejahtera. Terdapat indikator pada dimensi responsivitas yang memperoleh persentase tertinggi yaitu karyawan koperasi selalu membantu setiap ada anggota yang kesulitan dalam mencari kebutuhannya serta cepat tanggap ketika anggota koperasi membutuhkan bantuan. 
3) Secara simultan variabel Strategi Bauran Pemasaran dan Kualitas Pelayanan memiliki dampak yang signifikan terhadap Tingkat Partisipasi Anggota sebagai Pengguna Koperasi, dan hasil dari pernyataan responden menilai bahawa partisipasi anggota sebagai pengguna koperasi dinilai tinggi, penilaian tertinggi terdapat pada indicator untuk membeli produk di mini market anggota membelanjakan uangnya secara tunai dan kredit.

4) Upaya-upaya yang dilakukan oleh Koperasi Karyawan Karya Sejahtera dalam meningkatkan partisipasi anggota sebagai pengguna koperasi yaitu dengan pemilihan produk, penetapan harga, promosi yang dilakukan serta tempat dimana koperasi berada ditetapakan berdasarkan rapat anggota dan disesuaikan dengan kebijakan perusahaan serta peningkatan kualitas pelayanan dilakukan dengan cara memberikan arahan, motivasi dan pelatihan kepada karyawan koperasi.

\section{Saran}

1) Berdasarkan hasil jawaban responden selaku anggota koperasi pada pelaksanaan startegi bauran pemasaran tentang kelengkapan merk produk maka disarankan untuk melengkapi merk-merk yang ada saat ini di koperasi ditambah jumlahnya sesuai dengan kebutuhan anggota melalui pertanyaan dan survey kepada anggota merk-merk yang sering dibutuhkan oleh anggota,

2) Kualiats pelayanan yang diberikan koperasi perlu ditingkatkan terutama dalam hal pemahaman karyawan tentang produk-produk yang ada dengan cara memberikan pelatihan, memberikan perhatian kepada anggota dari karyawan terhadap anggota yang berkunjung ke koperasi dengan cara memberikan motivasi dan disiplin keramah tamahan kepada karyawan

3) Tingkat partisipasi anggota akan meningkat apabila pengurus koperasi melakukan hal-hal sebagi berikut:

a) Memberikan pemahaman kepada anggota pentingnya kesadaran berkoperasi bahwa memanfaatkan pasilitas koperasi menguntungkan kepada anggota

b) Anggota akan menyadari bahwa belanja di koperasi lebih baik dari tempat lain apabila pengurus koperasi secara terus-menerus melakukan strategi yang tepat dan pelayanan yang baik secara konsisten.

c) Rendahnya jumlah transaksi anggota di koperasi karena ada jumlah pembelanjaan kredit yang dibatasi dan pembatasan jumlah kredit tersebut tidak sesuai dengan kebutuhan tiap-tiap anggota, untuk itu perlu di kaji ulang jumlah batas kredit yang disediakan saat ini yaitu dengan cara meeningkatkan jumlah batas kredit yang diberikan melalui penyesuaian dengan jumlah pendapatan yang diterima anggota sebagai karyawan perusahaan.

\section{DAFTAR PUSTAKA}

Anoraga, Panji. (2003). Manajemen Koperasi Teori dan Praktek, Jakarta: Batara

Buchori Alma. (2014). Manajemen Pemasaran dan pemasaran Jasa; Bandung: Alfabeta.

Harun Al Rasyid. (1994). Pokok Pokok Materi metodelogi Penelitian Untuk Penulisan Skrips, Jakarta: Ghalia Indonesia

Henel, Alfred. (2005). Organisasi Koperasi, Yogyakarta: Graha Ilmu.

Henri Ma'ruf. (2005). Pemasaran Ritel. Jakarta; Gramedia

Kotler, Philip. (2002). Prinsip-Prinsip Pemasaran, Jakarta: Erlangga

Kotler, Philip. (2005). Manajemen Pemasaran Edisi 11, Jakarta: PT. Indeks Kelompok Media

Kotler, Philip. (2012). Marketing Managemen, New jersey: Prentice Hall

Kotler Philip \& Kavin Line, (2007). Manajemen Pemasaran, Jakarta: Gramedia

Kotler Philip \& Amrstrong, Gary. (2013). Prinsip-Prinsip Pemasaran edisi 12, Jakarta: Erlangga

Lupiyoadi. (2001). Manajemen Pemasaran Jasa, Jakarta: Salemba Empat

Ramudi Arifin. (2006). Ekonomi Koperasi, Jatinangor: Ikopin Press

Ramudi Arifin. (2013). Koperasi Sebagai Perusahaan. Jatinangor: Ikopin Press

Revisond Baswir. (2000). Koperasi Indonesia. Yogyakarta: BPFE.

Rofke. Jochen. (2000). Ekonomi Koperasi, Jakarta: Salemba Empat.

Supranto, J (2008). Pengukuran Tingkat kepuasan Pelanggan, Jakarta: Rineka Cipta

Sartono, Jonathan (2011). Metode Penelitian Kuantitatif dan Kualitatuf, Yogyakrata: Graha Ilmu

Sugiyono (2011). Metode Penelitian Kuantitatif Kualitatif dan $R \& D$, Alfabeta, Bandung 
Tjiptono, Fandy (2003), Total Quality Manajemen. Yogyakarta. Andi Offset

Tjiptono,Fandy \& Chandra (2012), Staretgi Pemasaran. Yogyakarta. Andi Offset

Philip Kotler dan Kavin Line, (2007). Manajemen Pemasaran, Jakarta: Gramedia. 

